\title{
Validation of Potato Early Blight Disease Forecast Models for Colorado Using Various Sources of Meteorological Data
}

\author{
David H. Gent and Howard F. Schwartz, Colorado State University, Department of Bioagricultural Sciences and \\ Pest Management, Fort Collins 80523-1177
}

\begin{abstract}
Gent, D. H., and Schwartz, H. F. 2003. Validation of potato early blight disease forecast models for Colorado using various sources of meteorological data. Plant Dis. 87:78-84.

Disease forecasts from regional or remotely sensed meteorological data free growers from infield weather data monitoring and may improve disease forecast implementation. This study was initiated to validate potato early blight forecast models in Colorado and to determine the influence of sources of meteorological data on forecast accuracy. Hourly temperatures were recorded by Campbell Scientific CR-10, Pessl Instruments $\mu$ Metos Model MCR300, and Spectrum Technologies Model 450 WatchDog weather stations and data loggers within potato fields, field-specific temperature estimations generated by mPOWER3/EMERGE from off-site weather stations, and regional COAGMET CR-10 weather stations. Mean hourly temperature deviations between mPOWER3/EMERGE or in-field stations and COAGMET varied from $0.93^{\circ} \mathrm{C}$ greater to $1.11^{\circ} \mathrm{C}$ less than COAGMET observations. Initial appearance of early blight lesions was predicted using a 300 physiological day threshold in commercial fields in each year from 1998 to 2001 and in experimental plots in each year from 1997 to 2001 as determined by COAGMET meteorological observations. All sources of meteorological data generated early blight forecasts within 6 days of each other across all locations and years. COAGMET weather stations should free potato growers and integrated pest management personnel from collecting in-field microclimatic data and speed the implementation of disease forecasting.
\end{abstract}

Additional keywords: Alternaria solani, Solanum tuberosum

Potato (Solanum tuberosum L.) is an economically important crop in Colorado, which contributed over $\$ 200$ million in cash receipts in 2001 (2). Between 1997 and 2001, potatoes were produced on more than 33,000 ha with a farm gate value of $\$ 97$ to $\$ 216$ million annually. Colorado is second only to Idaho in production of fresh market potatoes, and fifth nationally in overall production (2). The top production areas are the San Luis Valley in southern Colorado, where 968,000 metric tons were harvested from 27,500 ha in 2001, and northeastern Colorado, with over 2,000 ha of production annually.

Early blight of potato, caused by Alternaria solani Sorauer, is a foliar pathogen of economic significance in Colorado. Management of this pathogen and the disease is achieved largely through protectant fungicide applications $(5,10-12)$ and is one of the most targeted diseases of potato nationwide, receiving an average of 4.6 fungicide applications annually (9). Grower adoption of forecast models that predict the onset of early blight with enough lead time to allow implementation

Corresponding author: H. F. Schwartz

E-mail: hfspp@lamar.colostate.edu

Accepted for publication 6 September 2002.

Publication no. D-2002-1115-01R

(C) 2003 The American Phytopathological Society of effective control measures can reduce crop inputs and improve profitability $(6,13,26,28,29)$. Reducing or eliminating unnecessary early-season applications through disease forecasting and sprayscheduling is a sound integrated pest management (IPM) strategy with potential benefits to the producer, public, and environment $(6,26,28,29)$.

Research in Colorado (10) and Idaho (5) indicated that initial early blight fungicide applications should correspond with the first appearance of airborne spores. Fungicide applications made prior to this do not contribute to disease suppression and are essentially wasted sprays that add expense $(6,28)$. Protectant fungicides initiated after the appearance of symptoms, however, often result in diminished disease control and potential yield losses (20).

Franc et al. (6) developed a growing degree-day (GDD) model to initiate spray programs in Colorado. A growing degreeday was determined by $\mathrm{DD}=\left[\left(T_{\max }-\right.\right.$ $\left.\left.T_{\min }\right) / 2\right]-7.2^{\circ} \mathrm{C}$ starting at planting. Growers who used the model saved three to four sprays without sacrificing disease control or yield. They reported that growers can expect primary lesions to develop at 361 GDD in the San Luis Valley and 625 GDD in northeastern Colorado. Individual growers could modify the model to adjust for their production practices, cultivars, and experiences.

Pscheidt and Stevenson (19) suggested that physiological days (P-Days), devel- oped by Sands et al. (22) to predict potato yield, could be used to predict potato development and early blight appearance similar to GDD. Sands et al. (22) noted that in diverse climates the P-Day model accurately predicted tuber initiation and bulking periods based on temperature. PDays are calculated similarly to GDD but are determined by P-Days = $\left\{1 / 24\left[5 P\left(T_{\min }\right)+8 P\left(2 T_{\min } / 3+T_{\max } / 3\right)+\right.\right.$ $\left.\left.8 P\left(2 T_{\max } / 3+T_{\min } / 3\right)+3 P\left(T_{\max }\right)\right]\right\}$, where $P(T)=0$ if $T<7^{\circ} \mathrm{C}, P(T)=10[1-(T-$ $\left.21)^{2} /(21-7)^{2}\right]$ if $7^{\circ} \mathrm{C} \leq T \leq 21^{\circ} \mathrm{C}$, and $P(T)$ $=10\left[1-(T-21)^{2} /(30-21)^{2}\right]$ if $21^{\circ} \mathrm{C} \leq T$ $\leq 30^{\circ} \mathrm{C}$ starting at emergence. This model assumes $7{ }^{\circ} \mathrm{C}$ minimum, $21^{\circ} \mathrm{C}$ optimum, and $30^{\circ} \mathrm{C}$ maximum growth temperatures for potato plant development, as well as diurnal fluctuations. Pscheidt and Stevenson (19) reported early blight was not a threat until a 300 P-Day threshold was reached, starting from emergence on latematuring cultivars in Wisconsin.

An intrinsic limitation of the previously described forecast systems $(13,15)$ is the requirement for in-field weather observation (3). Grower acceptance and adoption of disease forecast systems could be improved if regional climatic data could be used as a proxy for in-field weather stations. Requiring growers and pest management personnel to install and maintain weather stations and manage data sets from each field is not practical or economically feasible and discourages the adoption of disease forecasting (16). If the empirical relationship between in-field and regional observations is described, disease forecasts could be effectively generated for an entire production area (3). Bourke (3) asserts that there is no practical alternative to using standard regional observations in disease forecasting, but the quality of disease prediction using off-site weather stations degrades with increasing distance from the field (7). Early-season observations before row closure tend to be similar at both scales of observation (8). A regional network of automated weather stations could provide a compromise between in-field data and synoptic-scale meteorological observations $(1,14,21)$. The concentration of agricultural production, relatively homogeneous landscape, and level topography (elevation changes generally less than $5 \mathrm{~m}$ over a given field) of northeastern Colorado suggest that an automated weather station network could function in lieu of in-field weather stations $(14,16)$. 
The purpose of this research was to: (i) compare temperature observations from remotely sensed simulated observations, in-field weather stations, and regional weather stations; (ii) validate and compare the 300 P-Day (19) forecast system for Colorado potato production areas to the current 625 GDD (6) potato early blight forecast system; and (iii) quantify the effect of meteorological data source upon PDay calculations.

\section{MATERIALS AND METHODS}

Weather monitoring. An automated regional network of 40 Campbell Scientific, Inc. (CSI) CR-10 weather stations (Campbell Scientific, Inc., Logan, UT) in the Colorado Agricultural Meteorological Network (COAGMET), as well as a computer system to process, archive, and disseminate data, was established in major crop production regions throughout Colorado beginning in the late 1980s (4). Weather data collected by COAGMET stations are transmitted daily by COM100 cellular phones into a mainframe computer at the Colorado Climate Center and are made available on the Internet. Each station is equipped with a Vaisala HMP35C temperature probe (Campbell Scientific) positioned $1.5 \mathrm{~m}$ from the ground. COAGMET stations are positioned on both irrigated and nonirrigated mowed grass sites. Hourly and daily COAGMET network regional meteorological data were collected year-round from 1997 to 2001, but only meteorological data from potato crop planting (1 May) to harvest (30 September) were used directly in this study.

Additional meteorological data were collected at the Colorado State University Agricultural Research, Development, and Education Center (ARDEC) near Fort Collins during 2000 and 2001 and at two locations, pivots 6 and 39, in northeastern Colorado near Fort Morgan from 1998 to 2001 by the private-sector firm mPOWER3/EMERGE (Greeley, CO), which provides site-specific meteorological data from remotely sensed and off-site instrumentation. Hourly and daily temperature data provided by mPOWER3/ EMERGE were generated by weighted interpolated means from three surrounding National Weather Service weather stations located at regional airports or other urban sites. Site-specific temperature generated by mPOWER3/EMERGE for ARDEC fields was generated from weather data collected at the Torrington Municipal Airport in Torrington, WY, the Centennial Airport near Denver, CO, and the Denver Nexrad weather station in Denver. Pivot 6 temperature data were generated from weather data collected at the Sidney $\mathrm{Mu}$ nicipal Airport in Sidney, NE, the AkronWashington County Municipal Airport in Akron, CO, and the Denver Nexrad weather station. Pivot 39 temperature data were derived from weather data collected at the Centennial Airport, the AkronWashington County Municipal Airport, and the Denver Nexrad weather station. Meteorological data provided by mPOWER3/ EMERGE can reportedly capture weather events at a resolution of $2 \mathrm{~km}^{2}$ according to mPOWER3/EMERGE, but do not capture micrometeorological variability (see the mPOWER3 website).

In-field micrometeorological conditions were monitored from 1998 to 2001 using CR-10 data loggers and CSI sensors as described previously, from 1999 to 2001 using $\mu$ Metos Model MCR300 weather stations (Pessl Instruments $\mathrm{GmbH}$, Weiz, Austria), and by Spectrum Model 450 WatchDog data loggers (Spectrum Technologies, Inc., Plainfield, IL) during the 2001 growing season. The CR-10 in-field station was equipped identically to the COAGMET network stations previously described. Temperature was recorded at a height of 0.45 to $0.55 \mathrm{~m}$ as measured from the top of the soil ridge, which is the bed formed during and after planting potato seed pieces and where the crop develops its roots and tubers. This height was above the canopy before row closure, but within the canopy from row closure until harvest. Row closure, when petioles from adjacent rows just meet in the middle of the furrow, occurred approximately 230 to 270 P-Days from emergence in northern Colorado with early maturing cultivars such as 'Russet Norkotah'. All $\mu$ Metos stations were equipped with SMT160-30 temperature sensors (Pessl Instruments $\mathrm{GmbH}$ ) that recorded temperature at $0.75 \mathrm{~m}$ above the soil ridge, which was above the potato canopy from crop emergence to harvest. Spectrum WatchDog data loggers were equipped with Model 450 internal temperature sensors (Spectrum Technologies). Spectrum data loggers and temperature sensors were positioned in the potato row $0.35 \mathrm{~m}$ above the soil ridge. The sensors were above the canopy until approximately 200 to 240 P-Days from emergence, and then within the upper potato crop canopy until harvest. All sensors on in-field Spectrum, CR-10, and $\mu$ Metos stations were positioned low enough to intercept irrigation water from overhead sprinklers from center pivot irrigation systems and at least $30 \mathrm{~m}$ from the field margin. Although the height of temperature observation within or above a crop canopy can have significant effects on microclimatic observations (17), we collected and evaluated the various sources of microclimatic and regional meteorological data as growers would collect and use it for early blight forecasting.

Comparison of temperature observations. Temperature observations and variation among in-field and regional data were compared from 1998 to 2001 in experimental plots at ARDEC and in commercial potato fields that are adjacent to the Front Range and in northeastern Colorado and vary from 60 to $100 \mathrm{~km}$ apart. In-field weather stations at ARDEC were located $0.3 \mathrm{~km}$ away from the ARDEC COAGMET station. Fields in Weld County, CO, near Greeley, Platteville, or Kersey were grouped and considered Front Range locations. The in-field station in the Front Range production area was located $2.2 \mathrm{~km}$ away from the Kersey COAGMET station. Fields in Morgan and Yuma counties near Fort Morgan and Yuma, respectively, were grouped and considered Northeastern Plains locations. In-field stations varied from 1.6 to $23.5 \mathrm{~km}$ away from the Fort Morgan or Yuma COAGMET stations, but averaged $14.9 \mathrm{~km}$ from the nearest COAGMET station.

Hourly mean and daily maximum and minimum temperature observations were analyzed as a simple linear regression $Y=$ $\alpha+\beta X$ using the nearest COAGMET station as the independent variable $X$ and the in-field station or mPOWER3/EMERGE interpolated data as the response variable $Y$ (SAS PROC REG, SAS Institute, Cary, NC). Although COAGMET stations record regional meteorological events, they were established as the baseline for comparison with in-field and mPOWER3/EMERGE temperature observations in this study because of their extensive coverage in the potato-producing areas in northeastern Colorado (station coverage of every 20 $\mathrm{km}^{2}$ or less) throughout all years of this study and the historical reliance of Colorado potato growers upon the COAGMET network for weather data access and disease forecasting (H. F. Schwartz, unpublished).

Although mPOWER3/EMERGE and COAGMET both rely upon regional meteorological instrumentation and observations, temperature data generated by these sources were compared to quantify mPOWER3/EMERGE deviations from COAGMET observations for growers interested in mPOWER3/EMERGE meteorological data for disease forecasting. Mean hourly and daily deviation, averaged over all hours or days in a given dataset, of observed temperature $(\Delta T)$ and absolute differences $(|\Delta T|)$ between COAGMET and CR-10, $\mu$ Metos, Spectrum, and mPOWER3/ EMERGE meteorological observations were also calculated to quantify in-field and regional variation. Positive or negative $\Delta T$ values indicate COAGMET observations that were greater than or less than infield or mPOWER3/EMERGE observations, respectively.

Comparison of P-Days and GDD for disease forecasting. Field surveys were conducted in commercial potato fields from 1997 to 2001 to identify the initial appearance of early blight in the Northeastern Plains and Front Range production areas. Surveys were conducted on a weekly basis beginning 3 weeks after emergence (approximately 21 May) and continued until vine kill (approximately 15 September), but the interval was shortened to 
every 3 to 5 days as the 300 P-Day and 625 GDD thresholds were approached. The number and location of commercial fields surveyed each year varied in relation to potato acreage planted, ranging from 6 to 12 fields each season that were less than 1 $\mathrm{km}$ to $20 \mathrm{~km}$ from the nearest COAGMET regional weather station. An average of 15 fields and 900 ha were surveyed each year from 1997 to 2001, with a mean distance of $8 \mathrm{~km}$ from the nearest COAGMET regional weather station.

Characteristic early blight lesions were confirmed to be $A$. solani by microscopic examination of conidial and conidiophore morphology. Northeastern fields surveyed were all irrigated by overhead sprinkler (center pivot), whereas most Front Range fields were surface furrow irrigated. Al- though the specific emergence date for each field was unknown, 1 May was assumed to be the emergence date for all surveyed fields. Potato producers in northeastern Colorado have historically targeted the early fresh market and rely upon early planting and emergence to successfully capture this market niche. Consequently, the majority of the crop (i.e., $75 \%$ or greater) is planted early and emerges between 7 and 10 days of 25 April to 1 May.

Field plots were also established at ARDEC in Fort Collins (elevation 1,557 m) with 'Russet Norkotah' potatoes from 1997 to 2001. Plots were established in early to mid-May and grown according to local production recommendations $(18,30)$. All plots were planted on $0.76-\mathrm{m}$ centers with seed pieces weighing approximately
50 to $80 \mathrm{~g}$ planted $0.15 \mathrm{~m}$ deep, spaced $0.21 \mathrm{~m}$ apart in the soil ridge. Irrigation was delivered via an overhead linear (1997 to 1999) or surface furrow (2000 to 2001) system. Untreated areas of the field were scouted thoroughly on a weekly basis early in the season to identify primary lesion appearance, but scouting intervals were shortened as model thresholds were approached.

A research website was created on a Linux operating system to allow for rapid historical and current meteorological data access and manipulation. The P-Day early blight forecast system was coded using the Perl programming language and installed into the research website for validation and adaptation. No modifications were made to the Sands et al. (22) original potato devel-

Table 1. Mean deviations and correlations of measured mean hourly $(T)$ and daily maximum $\left(T_{\max }\right)$ and minimum temperature $\left(T_{\min }\right)$ with various weather stations in relation to Colorado Agricultural Meteorological Network (COAGMET) regional observations at three locations from 1998 to 2001

\begin{tabular}{|c|c|c|c|c|c|c|c|c|c|c|c|c|c|}
\hline $\begin{array}{l}\text { Weather } \\
\text { stationw }^{w}\end{array}$ & Year & $\begin{array}{l}\text { Days of } \\
\text { obser- } \\
\text { vation }\end{array}$ & $\begin{array}{c}\text { Dates of } \\
\text { observation } \\
\text { (day of yr) }\end{array}$ & $\begin{array}{c}\text { Distance to } \\
\text { COAGMET } \\
\text { station }(\mathbf{k m})^{\mathrm{x}}\end{array}$ & $\begin{array}{c}\text { Mean } \\
\Delta T \\
\left({ }^{\circ} \mathbf{C} / \mathbf{h}\right)^{y}\end{array}$ & $\begin{array}{c}\text { Mean } \\
|\Delta T| \\
\left({ }^{\circ} \mathbf{C} / \mathbf{h}\right)^{\mathbf{y}}\end{array}$ & $R^{2 \mathrm{z}}$ & $\begin{array}{c}\text { Mean } \\
\Delta T_{\max } \\
\left({ }^{\circ} \mathbf{C} / \text { day }\right)^{\mathrm{y}}\end{array}$ & $\begin{array}{c}\text { Mean } \\
\left|\Delta T_{\max }\right| \\
\left({ }^{\circ} \mathbf{C} / \text { day }\right)^{\mathrm{y}}\end{array}$ & $R^{2 \mathrm{z}}$ & $\begin{array}{c}\text { Mean } \\
\Delta T_{\min } \\
\left({ }^{\circ} \mathbf{C} / \text { day }\right)^{\mathrm{y}}\end{array}$ & $\begin{array}{l}\text { Mean } \\
\left|\Delta T_{\min }\right| \\
\left({ }^{\circ} \mathbf{C} / \mathbf{h}\right)^{\mathbf{y}}\end{array}$ & $R^{2 \mathrm{z}}$ \\
\hline \multicolumn{14}{|l|}{ ARDEC } \\
\hline CR10 & 2001 & 114 & $130-244$ & $<1$ & 0.01 & 2.78 & 0.72 & -0.66 & 3.29 & 0.47 & 0.23 & 1.60 & 0.64 \\
\hline$\mu$ Metos & 2001 & 114 & $130-244$ & $<1$ & -0.10 & 2.12 & 0.85 & 0.80 & 0.89 & 0.98 & -0.71 & 0.73 & 0.99 \\
\hline Spectrum & 2001 & 114 & $130-244$ & $<1$ & -0.52 & 3.08 & 0.73 & -1.47 & 1.66 & 0.92 & 0.01 & 0.52 & 0.96 \\
\hline $\begin{array}{l}\text { mPOWER3/ } \\
\text { EMERGE }\end{array}$ & 2001 & 114 & $130-244$ & 130 & -0.93 & 4.15 & 0.53 & -1.00 & 13.00 & 0.95 & -2.67 & 3.11 & 0.67 \\
\hline CR10 & 2000 & 149 & $125-274$ & $<1$ & -0.72 & 3.05 & 0.66 & -1.50 & 3.20 & 0.23 & -0.05 & 1.80 & 0.42 \\
\hline$\mu$ Metos & 2000 & 149 & $125-274$ & $<1$ & -0.14 & 2.11 & 0.85 & 0.60 & 0.90 & 0.96 & -0.85 & 0.86 & 0.91 \\
\hline $\begin{array}{l}\text { mPOWER3/ } \\
\text { EMERGE }\end{array}$ & 2000 & 149 & $125-274$ & 130 & NA & NA & NA & -2.50 & 2.50 & 0.92 & -2.24 & 3.23 & 0.46 \\
\hline CR10 & 1999 & 148 & $125-273$ & $<1$ & -0.39 & 2.54 & 0.72 & -1.49 & 3.20 & 0.48 & 0.10 & 1.44 & 0.70 \\
\hline$\mu$ Metos & 1999 & 148 & $125-273$ & $<1$ & -0.35 & 0.97 & 0.78 & 0.00 & 0.60 & 0.91 & -0.82 & 0.83 & 0.89 \\
\hline CR10 & 1998 & 99 & $138-237$ & $<1$ & -0.72 & 2.34 & 0.81 & -0.97 & 1.39 & 0.94 & -0.82 & 0.87 & 0.93 \\
\hline $\begin{array}{l}\text { Front Range } \\
\mu \text { Metos }\end{array}$ & 2000 & 128 & $125-253$ & 2 & -0.06 & 2.08 & 0.86 & 0.65 & 1.30 & 0.93 & -0.71 & 0.98 & 0.94 \\
\hline \multicolumn{14}{|c|}{ Northeastern Plains } \\
\hline CR10 & 2001 & 106 & $151-257$ & 24 & 0.71 & 1.62 & 0.92 & 1.62 & 0.92 & 0.81 & 0.43 & 0.64 & 0.97 \\
\hline$\mu$ Metos & 2001 & 106 & $151-257$ & 24 & 1.11 & 3.11 & 0.65 & 3.11 & 0.65 & 0.34 & 0.55 & 1.60 & 0.69 \\
\hline Spectrum & 2001 & 106 & $151-257$ & 24 & 0.99 & 3.16 & 0.73 & 3.16 & 0.73 & 0.31 & 1.78 & 2.10 & 0.68 \\
\hline $\begin{array}{l}\text { mPOWER3/ } \\
\text { EMERGE-39 }\end{array}$ & 2001 & 106 & $151-257$ & 85 & 0.64 & 5.34 & 0.30 & 5.34 & 0.30 & 0.39 & -2.50 & 2.76 & 0.62 \\
\hline $\begin{array}{l}\text { mPOWER3/ } \\
\text { EMERGE-6 }\end{array}$ & 2001 & 106 & $151-257$ & 91 & 0.84 & 4.52 & 0.46 & 4.52 & 0.46 & 0.77 & -0.96 & 2.48 & 0.64 \\
\hline$\mu$ Metos \#1 & 2000 & 133 & $124-257$ & 2 & 1.00 & 2.26 & 0.84 & 1.54 & 1.91 & 0.83 & 0.22 & 0.62 & 0.92 \\
\hline $\mu$ Metos \#2 & 2000 & 133 & $124-257$ & 2 & 1.01 & 1.41 & 0.96 & 1.69 & 1.84 & 0.95 & 0.11 & 1.13 & 0.89 \\
\hline $\begin{array}{l}\text { mPOWER3/ } \\
\text { EMERGE-39 }\end{array}$ & 2000 & 133 & $124-257$ & 85 & NA & NA & NA & 0.96 & 1.26 & 0.96 & -1.47 & 2.96 & 0.51 \\
\hline $\begin{array}{l}\text { mPOWER3/ } \\
\text { EMERGE-6 }\end{array}$ & 2000 & 133 & $124-257$ & 91 & NA & NA & NA & 0.87 & 1.23 & 0.95 & -1.07 & 2.69 & 0.56 \\
\hline $\begin{array}{l}\text { mPOWER3/ } \\
\text { EMERGE-39 }\end{array}$ & 1999 & 152 & $121-273$ & 85 & NA & NA & NA & 0.05 & 2.96 & 0.56 & 0.37 & 1.82 & 0.74 \\
\hline $\begin{array}{l}\text { mPOWER3/ } \\
\text { EMERGE-6 }\end{array}$ & 1999 & 152 & $121-273$ & 91 & NA & NA & NA & 0.17 & 3.08 & 0.56 & -0.21 & 1.86 & 0.72 \\
\hline $\begin{array}{l}\text { mPOWER3/ } \\
\text { EMERGE-39 }\end{array}$ & 1998 & 152 & $121-273$ & 85 & NA & NA & NA & 1.58 & 1.75 & 0.95 & -0.57 & 2.32 & 0.60 \\
\hline $\begin{array}{l}\text { mPOWER3/ } \\
\text { EMERGE-6 }\end{array}$ & 1998 & 152 & $121-273$ & 91 & NA & NA & NA & 1.33 & 1.50 & 0.96 & -0.59 & 2.52 & 0.57 \\
\hline
\end{tabular}

${ }^{\text {w }}$ Numbers 1 and 2 following $2000 \mu$ Metos in-field stations represent different weather stations placed in separate fields in the Northeastern Plains production area. The numbers 39 and 6 following mPOWER3/EMERGE represent different fields within the Northeastern Plains for which site-specific weather was generated. All other stations listed represent one weather station per data set.

$\mathrm{x}$ The distance of the nearest COAGMET regional weather station to the in-field stations presented varied depending on the location of commercial potato fields in a given year. The Colorado State University Agricultural Research, Development, and Education Center (ARDEC) COAGMET station was used for all ARDEC experimental plots, Kersey COAGMET stations for Front Range commercial field, and Yuma or Fort Morgan COAGMET stations for Northeastern Plains commercial fields. Site-specific temperature generated by mPOWER3/EMERGE was derived from the weighted interpolated means from three National Weather Service weather stations and is given as the mean distance of the three stations.

${ }^{y}$ Mean hourly or daily deviation among in-field or mPOWER3/EMERGE observations compared with nearest COAGMET regional weather station averaged over all data points in the data set. NA = not available.

${ }^{\mathrm{z}}$ Regression coefficient determined by simple linear regression $Y=\alpha+\beta X$, where COAGMET observations $=X$, in-field or mPOWER3/EMERGE observations $=Y$. 
opment model. Accumulated P-Days were calculated from the various in-field and regional stations to quantify the differences in microclimatic and regional weather observations on disease forecast accuracy and precision. The accuracy of in-field and regional weather sources in forecasting early blight development in a given field was assessed by comparing observations from the in-field weather stations, mPOWER3/EMERGE interpolation routines, and nearest COAGMET regional weather station.

\section{RESULTS}

Comparison of temperature observations. In-field and mPOWER3/EMERGE mean hourly temperature deviations from COAGMET observations varied from $1.11^{\circ} \mathrm{C}$ to $-0.93^{\circ} \mathrm{C}$, depending on location and source of meteorological data (Table 1). Regression coefficients for mean hourly temperature varied from 0.30 with mPOWER3/EMERGE at pivot 39 in northeastern Colorado in 2001, to 0.96 with an in-field $\mu$ Metos station in northeastern Colorado in 2000. Across all sites and years considered in this study, in-field station hourly temperature observations had correlation coefficients $\left(R^{2}\right)$ greater than 0.65 , with $\Delta T$ averaging $-0.22,0.35$, and $0.24^{\circ} \mathrm{C}$ with CR-10, $\mu$ Metos, and Spectrum stations, respectively (Table 2). Averaged over all data points, mean mPOWER3/EMERGE hourly $\Delta T$ were $0.18^{\circ} \mathrm{C}$ greater than COAGMET observations with a corresponding regression coefficient of $R^{2}=0.43$.

Of all the stations included in this study, $\mu$ Metos in-field stations had the least variable hourly temperature observations and were the most highly correlated with COAGMET (mean $R^{2}=0.83$ ). Temperature interpolation routines by mPOWER3/ EMERGE generated the most variable observations (mean $R^{2}=0.43$ across all locations) of any station evaluated, with mean hourly $|\Delta T|$ observations deviating $4.67^{\circ} \mathrm{C}$ from COAGMET observations averaged over all sites considered in this study.

For all locations and years, the mean daily high temperature observation deviations varied from $-0.60^{\circ} \mathrm{C}$ with CR-10 $\left(R^{2}\right.$ $=0.59)$ to $1.20^{\circ} \mathrm{C}$ with $\mu$ Metos $\left(R^{2}=0.84\right)$, whereas mean daily low temperature deviations ranged from $-1.19^{\circ} \mathrm{C}$ with POWER3/EMERGE $\left(R^{2}=0.61\right)$ to $0.89^{\circ} \mathrm{C}$ with in-field Spectrum stations $\left(R^{2}=0.82\right)$ (Table 2). The in-field CR-10 weather station placed in experimental plots at ARDEC recorded greater mean daily high temperatures than the nearby (less than 1 $\mathrm{km})$ COAGMET regional weather station in each year of this study. At ARDEC, the daily high temperature averaged over all years was $1.16^{\circ} \mathrm{C}$ higher. In a commercial field under center pivot irrigation in northeastern Colorado, however, the CR-10 recorded mean daily high temperatures of $1.62^{\circ} \mathrm{C}$ less than the COAGMET regional weather station. Mean daily low tempera-

Table 2. Temperature variability between in-field or mPOWER3/EMERGE meteorological observations and Colorado Agricultural Meteorological Network (COAGMET) regional observations averaged over locations and years

\begin{tabular}{|c|c|c|c|c|c|c|c|c|c|c|}
\hline \multirow{2}{*}{$\begin{array}{l}\text { Weather } \\
\text { station }\end{array}$} & \multirow{2}{*}{$\begin{array}{l}\text { Location-yrs } \\
\text { of data }^{x}\end{array}$} & \multicolumn{3}{|c|}{ Hourly temperature } & \multicolumn{3}{|c|}{ Daily maximum temperature } & \multicolumn{3}{|c|}{ Daily minimum temperature } \\
\hline & & Mean $\Delta T^{y}$ & Range $^{y}$ & $\mathbf{S D}^{\mathbf{z}}$ & $\operatorname{Mean} \Delta \mathbf{T} \mathbf{x}^{\mathbf{y}}$ & Range & $\mathbf{S D}^{\mathbf{z}}$ & $\operatorname{Mean} \Delta \mathbf{T} \mathbf{x}^{\mathbf{y}}$ & Range & $\mathbf{S D}^{\mathbf{z}}$ \\
\hline CR10 & 5 & -0.22 & $-0.72-0.71$ & 0.60 & -0.60 & $-1.49-1.62$ & 1.29 & -0.02 & $-0.82-0.43$ & 0.48 \\
\hline Spectrum & 2 & 0.24 & $-0.52-0.99$ & 1.07 & 0.85 & $-1.47-3.16$ & 3.27 & 0.89 & $0.01-1.78$ & 1.25 \\
\hline$\mu$ Metos & 7 & 0.35 & $-0.35-1.11$ & 0.65 & 1.20 & $0.00-1.69$ & 1.02 & -0.32 & $-0.85-0.22$ & 0.59 \\
\hline $\begin{array}{l}\text { mPOWER3/ } \\
\text { EMERGE }\end{array}$ & 10 & 0.18 & $-0.93-0.84$ & 0.97 & 1.13 & $-2.50-5.34$ & 2.34 & -1.19 & $-2.67-0.37$ & 1.02 \\
\hline
\end{tabular}

${ }_{\mathrm{x}}$ Three location-years of hourly data were available for mPOWER3/EMERGE, but 10 location-years were available for daily data.

y Mean calculated from each location-year's mean hourly or daily deviation among in-field or mPOWER3/EMERGE observations compared with nearest COAGMET regional weather station averaged over all data points in the data set. Negative values indicate the in-field or mPOWER3/EMERGE observation was greater than the corresponding COAGMET observations, whereas positive values indicate in-field or mPOWER3/EMERGE observations were less than the COAGMET observation.

${ }^{\mathrm{z}} \mathrm{SD}=$ standard deviation.

Table 3. The relationship between first appearance of potato early blight lesions and accumulated physiological days (P-Days) and growing degree-days (GDD) as measured by Colorado Agricultural Meteorological Network (COAGMET) regional weather stations at three locations in Colorado during 1997 to 2001

\begin{tabular}{|c|c|c|c|c|c|c|c|}
\hline Year & $\begin{array}{l}\text { First lesion } \\
\text { date }\end{array}$ & $\begin{array}{l}\text { Accrued } \\
\text { P-Days }{ }^{x}\end{array}$ & $\begin{array}{l}\text { 300 P-Day } \\
\text { date }^{y}\end{array}$ & $\begin{array}{c}\text { Forecast lead } \\
\text { time (days) }\end{array}$ & Accrued GDD $^{x}$ & 625 GDD date ${ }^{y}$ & $\begin{array}{c}\text { Forecast lead } \\
\text { time (days) }\end{array}$ \\
\hline \multicolumn{8}{|c|}{ ARDEC $^{z}$} \\
\hline 2001 & 17 July & 317 & 15 July & 2 & 775 & 7 July & 10 \\
\hline 2000 & 6 July & 325 & 3 July & 3 & 643 & 5 July & 1 \\
\hline 1999 & 21 July & 358 & 15 July & 7 & 724 & 14 July & 8 \\
\hline 1998 & 14 July & 346 & 8 July & 6 & 696 & 9 July & 5 \\
\hline 1997 & 8 Aug & 550 & 7 July & 32 & 1,048 & 8 July & 31 \\
\hline \multicolumn{8}{|c|}{ Front Range } \\
\hline 2001 & 26 June & 342 & 20 June & 6 & 589 & 23 June & 3 \\
\hline 2000 & 21 June & 320 & 19 June & 2 & 671 & 18 June & 3 \\
\hline 1999 & 21 June & 316 & 19 June & 2 & 529 & 28 June & -7 \\
\hline 1998 & 22 June & 324 & 19 June & 3 & 553 & 28 June & -5 \\
\hline 1997 & 9 June & 252 & 15 June & -6 & 463 & 23 June & -14 \\
\hline \multicolumn{8}{|c|}{ Northeastern Plains } \\
\hline 2001 & 28 June & 347 & 19 June & 9 & 712 & 23 June & 5 \\
\hline 2000 & 10 July & 447 & 17 June & 23 & 1,006 & 11 June & 29 \\
\hline 1999 & 21 June & 321 & 18 June & 3 & 542 & 27 June & -6 \\
\hline 1998 & 22 June & 324 & 20 June & 2 & 592 & 25 June & -3 \\
\hline 1997 & 17 June & 293 & 19 June & -2 & 528 & 24 June & -7 \\
\hline
\end{tabular}

$\mathrm{x}$ Accrued P-Days from emergence or GDD from planting to primary lesion appearance.

${ }^{\mathrm{y}}$ Threshold values for early blight lesion appearance are $300 \mathrm{P}$-Days from emergence and 625 GDD. A P-Day is calculated as P-Days $=\left\{1 / 24\left[5 \mathrm{P}\left(T_{\min }\right)+\right.\right.$ $\left.\left.8 \mathrm{P}\left(2 T_{\min } / 3+T_{\max } / 3\right)+8 \mathrm{P}\left(2 T_{\max } / 3+T_{\min } / 3\right)+3 \mathrm{P}\left(T_{\max }\right)\right]\right\}$, where $P(T)=0$ if $T<7^{\circ} \mathrm{C}, P(T)=10\left[1-(T-21)^{2} /(21-7)^{2}\right]$ if $7^{\circ} \mathrm{C} \leq T \leq 21^{\circ} \mathrm{C}$, and $P(T)=$ $10\left[1-(T-21)^{2} /(30-21)^{2}\right]$ if $21^{\circ} \mathrm{C} \leq T \leq 30^{\circ} \mathrm{C}$ starting at emergence. A GDD is calculated according to DD $=\left[\left(T_{\max }-T_{\min }\right) / 2\right]-7.2^{\circ} \mathrm{C}$ starting at planting.

${ }^{\text {z }}$ Colorado State University Agricultural Research, Development, and Education Center. 
ture observations recorded by mPOWER3/ EMERGE averaged over all locations and years were $1.19^{\circ} \mathrm{C}$ greater than the corresponding COAGMET observation, presumably from urban heat island effects at

Comparison of P-Days and GDD for disease forecasting. Early blight was consistently found in all production regions study (Table 3). The first lesion appeared in commercial fields between 9 June and 10 July and after the accumulation of 300 P-Days in all years except 1997, according to the nearest COAGMET station. In research plots at ARDEC, initial appearance varied from 6 July to 8 August and was not National Weather Service station locations. and years throughout the duration of this

observed before the 300 P-Day threshold was reached.

300 P-Day model. Primary early blight lesion appearance at ARDEC ranged from 317 to 550 accumulated P-Days (as calculated by the ARDEC COAGMET station), which provided 2 to 32 days of lead time (Table 3). Lead time was defined in this study as the time between forecasted disease and actual disease appearance dates, where a negative value indicates disease was observed before the forecasted date was reached. Forecasts were generated on average $10 \pm 12.5$ (standard deviation of error) days before initial disease appearance, but lesions were not detected before 300 P-Days. The first lesion appearance in

Table 4. Comparison of meteorological data source on physiological day (P-Day) accumulation and potato early blight (Alternaria solani) disease forecast accuracy from 1998 to 2001

\begin{tabular}{|c|c|c|c|}
\hline $\begin{array}{l}\text { Source of } \\
\text { meteorological data }\end{array}$ & Year & 300 P-Day date ${ }^{z}$ & $\begin{array}{c}\text { Forecast lead time } \\
\text { (days) }\end{array}$ \\
\hline \multicolumn{4}{|l|}{ ARDEC } \\
\hline CR10 & 2001 & 14 July & 3 \\
\hline$\mu$ Metos & 2001 & 15 July & 2 \\
\hline Spectrum & 2001 & 17 July & 0 \\
\hline mPOWER3/EMERGE & 2001 & 16 July & 1 \\
\hline COAGMET & 2001 & 15 July & 2 \\
\hline CR10 & 2000 & 3 July & 3 \\
\hline$\mu$ Metos & 2000 & 1 July & 5 \\
\hline mPOWER3/EMERGE & 2000 & 3 July & 3 \\
\hline COAGMET & 2000 & 3 July & 3 \\
\hline CR10 & 1999 & 13 July & 9 \\
\hline$\mu$ Metos & 1999 & 17 July & 5 \\
\hline COAGMET & 1999 & 15 July & 7 \\
\hline CR10 & 1998 & 9 July & 5 \\
\hline COAGMET & 1998 & 8 July & 6 \\
\hline \multicolumn{4}{|l|}{ Front Range } \\
\hline$\mu$ Metos \#1 & 2000 & 16 June & 5 \\
\hline $\mu$ Metos \#2 & 2000 & 14 June & 7 \\
\hline COAGMET & 2000 & 20 June & 1 \\
\hline \multicolumn{4}{|l|}{ Northeastern Plains-Yuma } \\
\hline$\mu$ Metos & 2001 & 27 June & 3 \\
\hline Spectrum & 2001 & 24 June & 4 \\
\hline COAGMET & 2001 & 20 June & 8 \\
\hline \multicolumn{4}{|c|}{ Northeastern Plains-Fort Morgan } \\
\hline mPOWER3/EMERGE-39 & 2001 & 19 June & 9 \\
\hline mPOWER3/EMERGE-6 & 2001 & 20 June & 8 \\
\hline COAGMET & 2001 & 21 June & 7 \\
\hline$\mu$ Metos & 2000 & 19 June & 21 \\
\hline mPOWER3/EMERGE-39 & 2000 & 18 June & 22 \\
\hline mPOWER3/EMERGE-6 & 2000 & 18 June & 22 \\
\hline COAGMET & 2000 & 19 June & 21 \\
\hline mPOWER3/EMERGE-39 & 1999 & 18 June & 3 \\
\hline mPOWER3/EMERGE-6 & 1999 & 18 June & 3 \\
\hline COAGMET & 1999 & 19 June & 2 \\
\hline mPOWER3/EMERGE-39 & 1998 & 20 June & 2 \\
\hline mPOWER3/EMERGE-6 & 1998 & 20 June & 2 \\
\hline COAGMET & 1998 & 19 June & 3 \\
\hline
\end{tabular}

y The nearest Colorado Agricultural Meteorological Network (COAGMET) regional weather station was used to generate the 300 P-Day threshold date for each location and year; Colorado State University Agricultural Research, Development, and Education Center (ARDEC) COAGMET station for ARDEC experimental plots, Kersey or Peckham COAGMET stations for Front Range commercial fields, and Yuma or Fort Morgan COAGMET stations for Northeastern Plains commercial fields. Numbers \#1 and \#2 following $2000 \mu$ Metos represent different weather stations placed in separate fields in the Northeastern Plains production area. The numbers 39 and 6 following mPOWER3/EMERGE represent different fields within the Northeastern Plains for which site-specific weather was generated. All stations listed represent one weather station per data set.

${ }^{\mathrm{z}}$ The threshold value for early blight lesion appearance is 300 P-Days from crop emergence. A PDay is calculated as P-Days $=\left\{1 / 24\left[5 P\left(T_{\min }\right)+8 P\left(2 T_{\min } / 3+T_{\max } / 3\right)+8 P\left(2 T_{\max } / 3+T_{\min } / 3\right)+\right.\right.$ $\left.\left.3 P\left(T_{\max }\right)\right]\right\}$, where $P(T)=0$ if $T<7^{\circ} \mathrm{C}, P(T)=10\left[1-(T-21)^{2} /(21-7)^{2}\right]$ if $7^{\circ} \mathrm{C} \leq T \leq 21^{\circ} \mathrm{C}$, and $P(T)=10\left[1-(T-21)^{2} /(30-21)^{2}\right]$ if $21^{\circ} \mathrm{C} \leq T \leq 30^{\circ} \mathrm{C}$ starting at emergence.
Front Range commercial fields varied from 252 to 342 P-Days and provided $1.4 \pm 4.5$ days of lead time. Only in 1997, when the first lesion was detected after 252 P-Days accumulated, did the model fail to provide at least 2 days of lead time. Similarly, the model accurately forecasted early blight appearance in commercial production fields in the Northeastern Plains in all years except 1997. First lesion appearance was predicted 2 to 23 days in advance of disease appearance in all seasons, except for 1997, when disease was observed at 292 P-Days, 2 days prior to reaching the threshold. The model, on average, alerted growers $7.0 \pm 9.8$ days before disease developed.

625 GDD model. Primary early blight lesions at ARDEC were observed between 696 and 1,048 GDD, providing 1 to 31 days of forecast lead time, respectively (Table 3). Mean forecast lead time was 11 \pm 11.7 days. Primary lesions did not develop before the model threshold was crossed throughout the duration of this study in experimental plots. In the Front Range, the model predicted disease 3 days before to 14 days after the first observed lesion, with a mean of $-4 \pm 7.2$, where negative values indicate disease appeared before the forecasted date. Only in 2000 and 2001 did the GDD provide 3 days of advanced warning of disease. Growers were provided with $3.6 \pm 15.0$ days of warning in the Northeastern Plains, but the model generated more than 3 days of advanced warning only in 2000 (29 days) and 2001 (5 days).

Regional and in-field weather data. Regional observations by COAGMET weather stations and mPOWER3/ EMERGE interpolation routines generated P-Day threshold dates within 6 days of infield observations across all production regions (Table 4). Spectrum data loggers had the smallest standard deviation in forecast lead time at 2.0 days, whereas COAGMET regional stations were the largest at 8.8 days. Mean forecast lead time ranged from 2.0 days with Spectrum data loggers to 7.5 days with mPOWER3/EMERGE (Table 5). Regional meteorological observations generated by COAGMET provided an improvement in forecast lead time compared with in-field stations, but improvements across all locations and years were 6 days or less (Tables 4 and 5).

\section{DISCUSSION}

The 300 P-Day forecast model predicted early blight lesion appearance in all Colorado production regions studied, using either in-field or regional meteorological observations. Only in 1 year of this study did this model fail to predict early blight before it was observed in a commercial field. Disease was accurately predicted in all years in the experimental plots. Additionally, the P-Day forecast model appears to be more sensitive than the GDD model, 
which some growers are currently using for timing early blight sprays.

P-Days are essentially a measurement of potato development and predict early blight onset because disease appearance and development is closely related to plant maturity. Although GDD values are also a measure of crop development, P-Days do consider optimum $\left(21^{\circ} \mathrm{C}\right)$ and high $\left(30^{\circ} \mathrm{C}\right)$ temperature thresholds, as well as diurnal variations in assigning values to a given day. In the original GDD model of Franc et al. (6), degree-days only consider the minimum temperature for crop development. The P-Day model generated more timely forecasts than GDD in commercial production regions considered in this study, and may be a better predictor of crop development and thus susceptibility to infection by $A$. solani.

Although Pscheidt and Stevenson (19) reported that delaying sprays until $300 \mathrm{P}-$ Days with 'Norgold Russet' resulted in increased disease severity, we did not observe disease before 300 P-Days accumulated in experimental plots with the highly susceptible cultivar 'Russet Norkotah'. Pscheidt and Stevenson (19) also noted that the field in their study was cropped to potatoes the previous season and suggested that the model threshold be lowered for such higher-risk disease situations. Similarly in New York, Shtienberg and Fry (27) reported that initial early blight lesions appeared 6 to 8 days earlier when the preceding crop was tomato or potato. Despite continuous cropping of potatoes during 2000 and 2001 at ARDEC, the model still provided 2 days of advanced warning before disease appearance.

Even though the 300 P-Day threshold accurately predicted host susceptibility in this study, the presence of the pathogen and favorable environmental conditions for infection and disease development are not considered in this model. Pscheidt and Stevenson (20) noted that while early blight lesions were observed after $300 \mathrm{P}$ Days, airborne spores, favorable weather for dispersal and infection, and host susceptibility did not simultaneously occur until 400 P-Days with late maturing cultivars (i.e., 'Russet Burbank') in Wisconsin. They suggested initiating sprays at $400 \mathrm{P}$ Days and then spraying as needed accord-

Table 5. The effect of meteorological data source upon mean forecast lead time and variability of 300 physiological day (P-Day) potato early blight predictive model, averaged over locations and years

\begin{tabular}{lccc}
\hline $\begin{array}{l}\text { Meteorological } \\
\text { data source }\end{array}$ & $\begin{array}{c}\text { Location-years } \\
\text { of data }^{\mathbf{y}}\end{array}$ & $\begin{array}{c}\text { Mean forecast } \\
\text { lead time (days) }\end{array}$ & Standard deviation \\
\hline COAGMET & 17 & 5.8 & 8.8 \\
mPOWER3/EMERGE & 10 & 7.5 & 8.0 \\
Spectrum & 2 & 2.0 & 2.0 \\
HMetos & 7 & 6.0 & 5.8 \\
CR-10 & 5 & 5.0 & 2.8 \\
\hline
\end{tabular}

y Three location-years of hourly data were available for mPOWER3/EMERGE, but 10 location-years were available for daily data.

${ }^{\mathrm{z}}$ Colorado Agricultural Meteorological Network. ing to cumulative severity values, which are based upon hours of leaf wetness and temperature, as recommended for A. solani by the tomato (FAST) forecast system (15). Under sprinkler irrigation with highly susceptible cultivars in eastern Colorado, however, delaying initial fungicide applications 10 to 14 days after primary lesion appearance results in significantly less disease suppression $(12,23,24)$.

Despite measured differences in temperature between in-field microclimatic data and COAGMET regional weather observations, the source of meteorological data had little impact upon early blight forecast accuracy. Early blight disease forecasts differed by 6 days or less across all years and locations considered in this study. Calculating potato physiological days requires only daily maximum and minimum temperatures, and only those which fall above or below the minimum, optimum, and maximum cardinal temperatures for crop development $\left(7,21\right.$, or $30^{\circ} \mathrm{C}$, respectively) influence the P-Days assigned to a given day. Daily maximum and minimum temperatures were the most highly correlated of all meteorological parameters evaluated. COAGMET observations were within $3.16^{\circ} \mathrm{C}$ of in-field station observations. When this is considered in relation to probe accuracy and microclimatic variation within the field, temperature differences among weather stations become insignificant in forecasting early blight.

Monteith and Unsworth (17) reported that temperatures typically vary by $3.0^{\circ} \mathrm{C}$ between crop canopies and the surrounding macroclimatic environment. In eastern Colorado potato fields, however, mean hourly differences were less than $1.11^{\circ} \mathrm{C}$ for all meteorological observations compared with COAGMET observations. Kuuseoks et al. (14) noted that simulated microclimatic observations generated by spatial interpolation of off-site stations varied on average by $1.8^{\circ} \mathrm{C}$ over the nearest station. Hourly differences between COAGMET and in-field stations were generally less than $1.11^{\circ} \mathrm{C}$, but mean daily minimum and maximum temperature differences as large as $3.16^{\circ} \mathrm{C}$ were recorded. Seem et al. (25) reported that simulated observations with a resolution of $0.1 \mathrm{~km}^{2}$ produced daily maximum and minimum temperature observations with accuracy of 85 to $95 \%$. Daily maximum and minimum temperatures for 61.5 and $42.3 \%$ of all sites in this study, respectively, had correlation coefficients greater than 0.80 when compared to COAGMET. COAGMET stations were able to explain at least $65 \%$ of the observed variability recorded by in-field stations across all years and locations. The ability of the regional COAGMET network to capture temperature variability within the field appears similar to that of simulated observations in New York (16).

This study demonstrates that growers can implement a P-Day based early blight disease forecast model and improve the timing of protectant fungicide applications and possibly reduce unnecessary earlyseason applications. This forecast model can also be accurately operated with regional weather data that can free growers and IPM personnel from the burden and expense of maintaining a series of in-field weather stations.

\section{ACKNOWLEDGMENTS}

This research was partially supported by grants from the Colorado Potato Growers Association Area III and Colorado State University Agricultural Experiment Station. We gratefully acknowledge technical support provided by John Kleist, Nolan Doesken, and Mark S. McMillian.

\section{LITERATURE CITED}

1. Agrios, G. E. 1997. Plant Pathology. 4th ed. Academic Press Inc., San Diego, CA.

2. Ament, D. 2002. Colorado Agricultural Statistics, Annual Report. Colorado Department of Agriculture, Denver.

3. Bourke, P. M. A. 1970. Use of weather information in the prediction of plant disease epiphytotics. Annu. Rev. Phytopathol. 8:345370 .

4. Doesken, N. J., Duke, H. R., Hamblen, B. L., Kleist, J., McKee, J. B., McMillan, M. S., and Schwartz, H. F. 1998. The Colorado agricultural meteorological network (COAGMET)-A unique collaborative system supporting Colorado agriculture. Conf. Agric. For. Meteorol., 23rd.

5. Douglas, D. R., and Groskopp, M. D. 1974. Control of early blight in eastern and southcentral Idaho. Am. Potato J. 51:361-368.

6. Franc, G. D., Harrison, M. D., and Lahman, L. K. 1988. A simple day-degree model for initiating chemical control of potato early blight in Colorado. Plant Dis. 72:851-854.

7. Gillespie, T. J., Srivastava, B., and Pitblado, R. E. 1993. Using operational weather data to schedule fungicide sprays on tomatoes in southern Ontario, Canada. J. Appl. Meteorol. 32:567-573.

8. Gudmestad, N. C., Enz, J. W., Preston, D. A., and Secor, G. A. 1995. Late blight forecasting and dissemination system using an automated weather monitoring system. Phytophthora 150:209-213.

9. Guenthner, J., Wiese, M., Pavlista, A., Sieczka, J., and Wyman, J. 1999. Assessment of pesticide use in the U.S. potato industry. Potato Res. 76:25-29.

10. Harrison, M. D., Livingston, C. H., and Oshima, N. 1965. Control of potato early blight in Colorado. I. Fungicidal spray schedules in relation to the epidemiology of the disease. Am. Potato J. 42:319-327.

11. Harrison, M. D., Livingston, C. H., and 
Oshima, N. 1965. Control of potato early blight in Colorado. II. Spore traps as a guide for initiating applications of fungicides. Am. Potato J. 42:333-340.

12. Harrison, M. D., and Venette, J. R. 1970. Chemical control of potato early blight and its effect on potato yield. Am. Potato. J. 47:81-86.

13. Krause, R. A., Massie, L. B., and Hyre, R. A. 1975. BLITECAST: A computerized forecast of potato late blight. Plant Dis. Rep. 59:95-98.

14. Kuuseoks, E., Liechty, H. O., Reed, D. D., and Dong, J. 1997. Relating site-specific weather data to regional monitoring networks in the lake states. For. Sci. 43:447-452.

15. Madden, L., Pennypacker, S. P., and MacNab, A. A. 1978. FAST, a forecast system for $A l$ ternaria solani on tomato. Phytopathology 68:1354-1358.

16. Magarey, R. D., Seem, R. C., Russo, J. M., Zack, J. W., Waight, K. T., Travis, J. W., and Oudemans, P. V. 2001. Site-specific weather information without on-site sensors. Plant Dis. 85:1216-1226.

17. Monteith, J. L., and Unsworth, M. H. 1990. Principles of Environmental Physics. Edward Arnold, New York.
18. Mortvedt, J. J., Soltanpour, P. N., Zink, R. T., and Davidson, R. D. 1996. Fertilizing Potatoes. Colorado State Univ. Coop. Ext. Serv. Fact Sheet \#0541, Fort Collins.

19. Pscheidt, J. W., and Stevenson, W. R. 1986. Comparison of forecasting methods for control of potato early blight in Wisconsin. Plant Dis. 70:915-920.

20. Pscheidt, J. W., and Stevenson, W. R. 1988. The critical period for control of early blight (Alternaria solani) of potato. Am. Potato J. 65:425-438.

21. Royer, M. H., Russo, J. M., and Kelley, J. G. W. 1989. Plant disease prediction using a mesoscale weather forecasting technique. Plant Dis. 73:618-624.

22. Sands, P. J., Hackett, C., and Nix, H. A. 1979. A model of the development and bulking of potatoes (Solanum tuberosum L.). Field Crops Res. 2:309-331.

23. Schwartz, H. F., McMillian, M. S., Gent, D. H., and Otto., K. L. 2000. 2000 Vegetable Pathology Results. Colorado State Univ. Coop. Ext. Serv. Bull., Fort Collins.

24. Schwartz, H. F., McMillian, M. S., and Otto, K. L. 1999. 1999 Vegetable Pathology Re- sults. Colorado State Univ. Coop. Ext. Sery. Bull., Fort Collins.

25. Seem, R. C., Magnus, H. A., and Hjonnevaag, V. 1991. High resolution weather information for plant protection. EPPO Bull. 21:355-364.

26. Shtienberg, D., and Fry, W. E. 1990. Field and computer simulation evaluation of sprayscheduling methods for control of early and late blight of potato. Phytopathology 80:772777.

27. Shtienberg, D., and Fry, W. E. 1990. Influence of host resistance and crop rotation on initial appearance of potato early blight. Plant Dis. 74:849-852.

28. Stevenson, W. 1993. Management of early and late blight. Pages 141-147 in: Potato Health Management. American Phytopathological Society, St. Paul, MN.

29. Stevenson, W. R. 1993. IPM for potatoes: A multifaceted approach to disease management and information delivery. Plant Dis. 77:309311.

30. Waskom, R. M. 1994. Best Management Practices for Irrigation Management. Colorado State Univ. Coop. Ext. Serv. Bull., Fort Collins. 